\title{
Addiction and Substance Abuse
}

\author{
Prashant Pandya* \\ GM-Program Management, CRS-RLS, India
}

Submission: June 11, 2017; Published: June 30, 2017

*Corresponding author: Prashant Pandya, GM-Program Management, CRS-RLS, India, Tel: +91-9967017172;

Email: drpandya18@gmail.com

\section{Introduction}

Addiction and substance abuse is common problem affecting adolescent, teen and adult alike worldwide. It is estimated that around 10 to $15 \%$ of people in United states affected by Addiction and substance abuse at some point of time in their lives. This leads to several problems and creating distress and develop tolerance. Drug abuse is also creating serious social problems like child abuse, violence, stress and destroys families [1-5].

\section{Abused drugs include}

- Cocaine

- Methamphetamine

- Marijuana

- Anabolic steroids

- Club drugs

- Heroin

- Inhalants

- $\quad$ Prescription drugs, including opioids

Addiction generally develops due to repeated usage of drug or substance which impact brain. This repeated stimulus will change the structure and functionality of brain and directly affecting eating, sex and sleep pattern. It is chronic and complex disease. Drugs directly affect into the brain's communication system and affecting nerve cells normal function of sending/ receiving and processing information. There are some drugs such as marijuna and heroin are having exactly similar structure like neurotransmitter, hence acting on brain receptors and sending abnormal messages and drugs like cocaine or methamphetamine release abnormally large amount of natural neurotransmitter and preventing normal recycling of brain chemicals. Such disruption disrupts normal communication pattern of brain. It's challenging for the person to stop taking abusing drug because of chronic relapsing brain disease [6-10] (Figure 1).

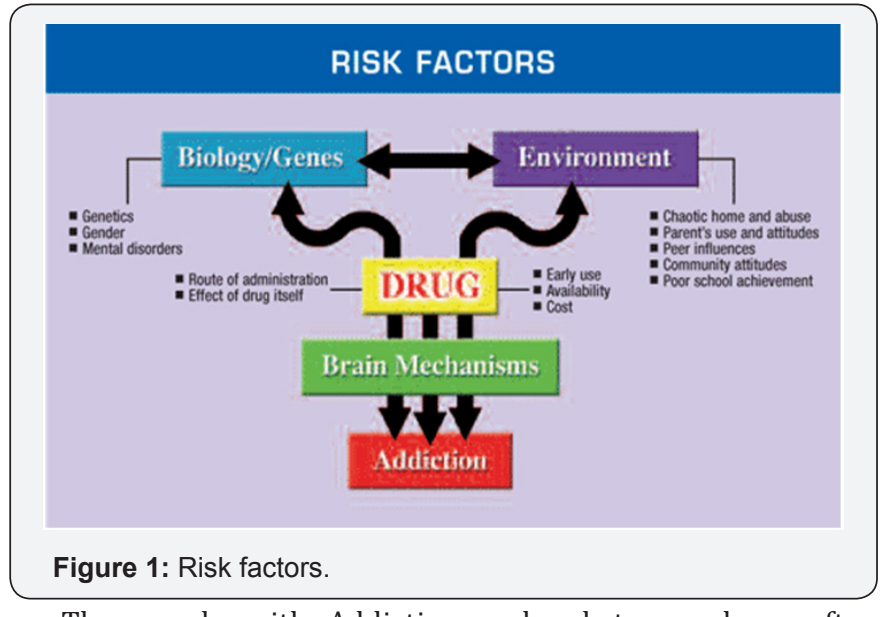

The people with Addiction and substance abuse often have several other medical issues like abnormal blood report, cardiovascular disease, diabetes, abnormal ECG etc. Many drugs damage peripheral nervous system and long term usage also affecting function like judgment, decision making, learning, behavior [11-13].

\section{What Causes Addiction and substance abuse?}

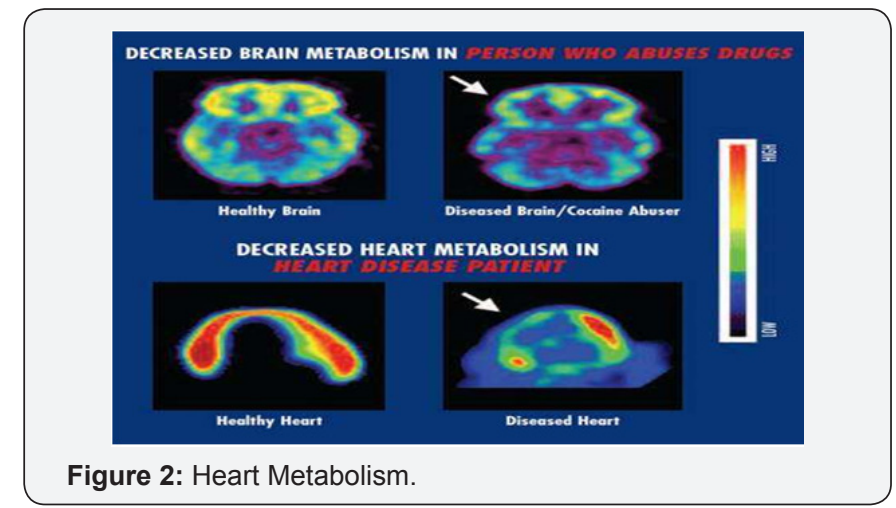

It is believed that family history and genetics play important role here. In addition there are several other factors affecting the 
same (Figure 2) like

- Type of addiction / substance abuse

- Family background and support system

- $\quad$ Age

- Frequency of usage

- Length of drug usage time.

- Environment

\section{Treatment options}

There are several treatment options currently available to counteract this problem. Generally combination treatment is useful and help for the quick recovery.

- Yoga

- Addiction treatment Medication

- Behavioral therapy / Counselling

- Treatment approaches are dependent on drug abuse pattern and concurrent medical conditions. The tailored approach helps to achieve prompt recovery and life without abuse drugs.

\section{References}

1. CASA Columbia (2012) Addiction medicine: Closing the gap between science and practice.

2. https://www.drugabuse.gov/

3. National Drug Intelligence Center (2011) The Economic Impact of Illicit Drug Use on American Society. Washington, DC: United States Department of Justice, USA.
4. U.S. Department of Health and Human Services (2004) The health consequences of smoking: a report of the Surgeon General. Atlanta, Georgia. U.S. Department of Health and Human Services, Centers for Disease Control and Prevention, National Center for Chronic Disease Prevention and Health Promotion, Office on Smoking and Health; Washington, DC, USA.

5. Rehm J, Mathers C, Popova S, Thavorncharoensap M, Teerawattananon Y, et al. (2009) Global burden of disease and injury and economic cost attributable to alcohol use and alcohol-use disorders. Lancet 373(9682): 2223-2233.

6. Centers for Disease Control and Prevention (2014) Best Practices for Comprehensive Tobacco Control Programs -2014. Atlanta: U.S. Department of Health and Human Services, Centers for Disease Control and Prevention, National Center for Chronic Disease Prevention and Health Promotion, Office on Smoking and Health.

7. Prevention, National Center for Chronic Disease Prevention and Health Promotion, Office on Smoking and Health, 2014.

8. Shankaran S, Lester BM, Das A, Bauer CR, Bada HS, et al. (2007) Impact of maternal substance use during pregnancy on childhood outcome. Semin Fetal Neonatal Med 12(2): 143-150.

9. Fowler JS, Volkow ND, Kassed CA, Chang L (2007) Imaging the addicted human brain. Sci Pract Perspect 3(2): 4-16.

10. Centers for Disease Control and Prevention (CDC). Alcohol-Related Disease Impact (ARDI). Atlanta, GA: CDC.

11. U.S. Department of Health and Human Services. The Health Consequences of Smoking-50 Years of Progress: A Report of the Surgeon General. Atlanta, GA: U.S. Department of Health and Human Services, Centers for Disease Control and

12. Lynskey MT, Heath AC, Bucholz KK, Slutske WS, Madden PA, et al. (2003) Escalation of drug use in early-onset cannabis users vs co-twin controls. JAMA 289(4): 427-433.

13. Substance Abuse and Mental Health Services Administration, Office of Applied Studies: Treatment Episode Data Set (TEDS): 1993-2003. National Admissions to Substance Abuse Treatment Services (DASIS Series: S-29, DHHS Publication No. SMA 05-4118). Rockville, Md: Department of Health and Human Services, 2005.

\section{Your next submission with Juniper Publishers} will reach you the below assets

- Quality Editorial service

- Swift Peer Review

- Reprints availability

- E-prints Service

- Manuscript Podcast for convenient understanding

- Global attainment for your research

- Manuscript accessibility in different formats ( Pdf, E-pub, Full Text, Audio)

- Unceasing customer service

Track the below URL for one-step submission https://juniperpublishers.com/online-submission.php 